\title{
PENGARUH BAURAN PEMASARAN JASA TERHADAP KEPUTUSAN WISATAWAN MENGUNJUNGI OBYEK WISATA PANTAI PANJANG KOTA BENGKULU
}

\author{
Yulius Wahyu Setiaadi, Marliza Ade Fitri \\ Program Studi Manajemen Fakultas Ekonomi Universitas Muhammadiyah Bengkulu
}

\begin{abstract}
ABSTRAK
Yulius Wahyu Setiaadi, Marliza Ade Fitri; Tujuan yang ingin dicapai dari penelitian ini adalah mengetahui pengaruh Bauran Pemasaran Jasa terhadap keputusan wisatawan mengunjungi objek wisata Pantai Panjang kota Bengkulu. Penelitian merupakan jenis penelitian survey yaitu penelitian yang mengambil sampel dari suatu populasi dan menggunakan kuesioner sebagai alat pengumpul data. Jenis data yang digunakan adalah data primer yang diperoleh melalui kuesioner. Populasi dalam penelitian ini adalah wisatawan yang berkunjung ke Pantai Panjang Bengkulu. Pengambilan sampel menggunakan teknik acedental sampling sebesar 100 orang responden. Metode analisis data yang digunakan adalah deskriptif statistik dan analisis regresi linier Sederhana.

Berdasarkan hasil penelitian diketahui bahwa: (1) Persamaan regresi yang diperoleh dari hasil analisis data adalah $\mathrm{Y}=11,012+0,227 \mathrm{X}$ yang berarti bahwa jika bauran pemasaran jasa (bukti fisik, proses, dan orang) semakin baik maka keputusan wisatawan berkunjung ke pantai panjang akan meningkat sebesar 0,227; (2) Koefisien korelasi berganda (R) sebesar 0,770; kondisi ini berarti bahwa hubungan antara bauran pemasaran jasa (bukti fisik, proses, dan orang) dengan kepuasan konsumen adalah cukup kuat; (3) Koefisien determinasi berganda $\left(R^{2}\right)$ sebesar 0,593; bermakna bahwa kenaikan dan penurunan keputusan wisatawan berkunjung ke Pantai Panjang sebesar 59,3 persen dapat dijelaskan oleh bauran pemasaran jasa (bukti fisik, proses, dan orang), sedangkan sisanya 40,7 persen dipengaruhi oleh faktor lain yang tidak diteliti; (4) Dari hasil pengujian hipotesis diperoleh nilai t-hitung sebesar 2,757 dengan signifikansi 0,07 < 0,05 yang berarti bahwa bauran pemasaran jasa (bukti fisik, proses, dan orang) berpengaruh signifikan terhadap keputusan wisatawan.
\end{abstract}

\begin{abstract}
Yulius Wahyu Setiaadi, Marliza Ade Fitri; Target of which wish to be reached from this research is to know influence of the Service Marketing Mix toward tourist decision to visit Pantai Panjang in Bengkulu City. Research represent type research of survey that is research taking sample from a population and use questionnaire as a means of compiler of the data. The data was used obtained primary data pass questionnaire distribution. Population in this research is tourist which a visit to Pantai Panjang Bengkulu. The method of intake sample was used total sampling technique equal to 100 respondents. The method of the data analyze was used descriptive statistic and simple regression linear analysis.

Pursuant to result of research known that : (1) Equation of obtained regression from result of data analysis is $Y=11,012+0,227 X$ the meaning that if service marketing mix (physical evidence, process, and people) is goodness, hence decision of tourist visiting to Pantai Panjang more higher equal to 0,227; (2) The correlation coefficient $(R)$ equal to 0,770; meaning the correlation between the service marketing mix (physical evidence, process, and people)with decision of tourist to visiting the Pantai Panjang is strength; (3) Value coefficient of multiple determination $\left(R^{2}\right)$ is 0,593; meaning that decision of tourist to visiting the Pantai Panjang equal to 59,3\% influenced by the service marketing mix (physical evidence, process, and people) anda while the rest 40,7\% influenced by other factor which do not check; (4) From result of hypothesis test, proven that the service marketing mix (physical evidence, process, and people) have an effect on significant toward decision of tourist to visiting the Pantai Panjang, proved with significant value 0,007 < 0,05 .
\end{abstract}

Key Words: The Implementation of Service Marketing Mix.

\section{LATAR BELAKANG}

Pariwisata merupakan salah satu sektor yang diandalkan pemerintah untuk memperoleh devisa dari penghasilan non migas. Disamping sebagai sumber perolehan devisa juga banyak memberikan sumbangan terhadap bidang-bidang lainnya, diantaranya menciptakan dan memperluas lapangan usaha, meningkatkan pendapatan masyarakat dan pemerintah. 
Pantai Panjang adalah salah satu pariwisata Provinsi Bengkulu yang dapat memberikan devisa dan memberikan lapangan usaha kepada masyarakat yang dapat menambah pendapatan masyarakat Bengkulu, Pantai Panjang juga menyediakan tempat yang nyaman untuk berwisata dikarenakan Pantai Panjang memiliki Pantai yang bagus, memiliki pasir yang putih dan airnya yang jernih, Pantai Panjang juga memiliki Sport Center, Restoran, Perbelanjaan, Hotel, dan Penyewaan sepeda, hal ini adalah salah satu produk dan jasa yang dapat menarik perhatian para wisatawan untuk mengunjungi Pantai Panjang..

Pariwisata hendaknya mempunyai produk-produk baru yang dapat memenuhi kebutuhan dan keinginan wisatawan yang membuat para wisatawan tertarik untuk berkunjung dan tidak bosan untuk memilih keputusan berkunjung kembali kepariwisataan yang ditawarkan, dengan dapat menimbulkan hal yang positif dan menarik di mata wisatawan sehingga secara tidak sengaja dengan adanya wisatawan yang datang dan merasa keinginannya terpenuhi atau berkunjung keparawisataan yang mempunyai kesan tersendiri bagi wisatawan sehingga bisa menjadikan promosi secara tidak sengaja terhadap pariwisata yang ditawarkan.

Perusahaan-perusahaan atau pengusaha pariwisata dapat menciptakan inovasi-inovasi produk yang dapat membuat hal-hal yang baru untuk menunjang keputusan wisatawan berkunjung ke pariwisata yang ditawarkan,sehingga inovasi-inovasi produk dapat menimbulkan terobosan-terobosan yang baru juga dapat menjadi modal utama pariwisata dalam menarik perhatian para wisatawan untuk berkunjung kepariwistaan yang ditawarkan.

Pariwisata dengan terobosan baru yang diberikan oleh pengusaha-pengusaha pariwisata dapat menarik perhatian para wisatawan untuk mengunjungi objek pariwisata yang ditawarkan, secara tidak sengaja dengan adanya hal ini dapat menambah atau meningkatkan jumlah pengunjung yang datang ke objek wisata yang ditawarkan, dengan meningkatnya jumlah pengunjung, secara tidak langsung tingkat pendapatan masyarakat sekitar objek wisata meningkat dan sekaligus pendapatan daerah bertambah juga tujuan pemerintah untuk mensejahterakan masyarakat dapat tercapai.

Untuk mengelola industri wisata yang baik dan profesional diperlukan kajian mendalam di antaranya adalah bahwa wisatawan adalah sumber dari pendapatan yang harus dilayani dengan baik untuk mereka senang dan nyaman untuk waktu tinggal di suatu daerah pariwisata yang lama, dengan hal ini hendaknya perusahaan atau pengusaha pariwisata dan masyarakat sekitar dapat berinovasi untuk dapat menimbul terobosan-terobosan produk atau jasa baru yang dapat membuat para wisatawan senang dan merasa nyaman, apakah bertahan lama di pariwisata yang ditawarkan, hal ini dapat membuat keuntungan untuk masyarakat, pemerintah, pengusaha atau perusahaan dan pariwisata itu sendiri.

\section{TINJAUAN LITERATUR}

Kegiatan bisnis selalu ada kompetisi. Perusahaan terus mencari pasar dan tidak pernah puas dengan pasar yang telah di dapatnya. Aktivitas pemasaran diarahkan untuk menciptakan perputaran yang memungkinkan perusahaan dalam mempertahankan kelangsungan hidup. Dalam hal ini, pemasaran memegang peranan penting dalam menentukan sukses atau tidaknya suatu bisnis. Untuk itu, perusahaan harus dapat memahami benar pemasaran bagi perusahaan yang ingin tetap bertahan. Di bawah ini terdapat beberapa pengertian pemasaran menurut para ahli.

Pemasaran adalah proses sosial yang di dalamnya individu dan kelompok mendapatkan apa yang mereka butuhkan dan inginkan dengan menciptakan, menawarkan dan secara bebas mempertukarkan produk yang bernilai dengan pihak lain (Kotler, 2000). Sedangkan Boyd, Walker dan Larreche (2000) menyatakan, pemasaran adalah suatu proses sosial yang melibatkan kegiatan-kegiatan penting yang memungkinkan individu dan perusahaan mendapatkan apa yang mereka butuhkan dan inginkan melalui pertukaran dengan pihak lain dan untuk mengembangkan hubungan pertukaran.

Berdasarkan definisi-definisi tersebut, dapat disimpulkan bahwa pemasaran merupakan suatu kegiatan manusia untuk memenuhi kebutuhan dan keinginan melalui proses penciptaan, penawaran dan pertukaran (nilai) produk dengan yang lain, dimana dalam pemasaran ini kegiatan bisnis dirancang untuk mendistribusikan barang-barang dari produsen kepada konsumen untuk mencapai sasaran serta tujuan organisasi.

\section{Konsep Pemasaran}

Pengertian konsep pemasaran adalah filsafat manajemen pemasaran untuk mencapai tujuan organisasi tergantung pada penentuan kebutuhan dan keinginan pasar sasaran dan memuaskan pelanggan secara lebih efektif dan efisien dari pada yang dilakukan pesaing (Kotler dan Armstrong, 2001).

Menurut Swasta dan Handoko (2001) ada 3 (tiga) hal yang merupakan unsur pokok konsep pemasaran dapat disebutkan yaitu :

1. Orientasi pada konsumen atau pasar atau pembeli. 
2. Volume penjualan yang menguntungkan.

3. Penyusunan kegiatan pemasaran secara integral (integrated marketing).

\section{Bauran Pemasaran (Marketing Mix)}

Tujuan Promotion Mix (Kotler, 2001): Memodifikasi tingkah laku, dapat diarahkan dengan adanya promosi, memberitahukan dengan memberikan informasi tentang adanya penawaran perusahaan, membujuk, karena diarahkan dan untuk mendorong pembelian, mengingatkan dengan melaksanakan promosi secara terus menerus agar produk yang ditawarkan selalu diingat konsumen, hal ini biasanya sangat dibutuhkan bila produk mencapai tingkat kedewasaan.

Marketing mix dalam pemasaran jasa dengan pemasaran manufaktur relatif berbeda, marketing mix dalam pemasaran manufaktur, komponen-komponen yang dipakai yaitu produk, price, place dan promotion. Dikarenakan jasa mempunyai sifat intangible atau tidak mempunyai wujud dan hanya bisa dirasakan oleh konsumen itu pun setelah konsumen mengkonsumsi jasa tersebut dan jasa relatif sulit untuk mengukur kualitasnya, maka marketing mix dalam pemasaran jasa relatif banyak, tujuh elemen pokok dalam bauran pemasaran jasa yang dimaksud oleh Alma (2004: 234) adalah sebagai berikut :

1. Harga (price) adalah suatu sitem manajemen perusahaan yang akan menentukan harga dasar yang tepat bagi produk atau jasa dan harus menentukan strategi yang menyangkut potongan harga, pembayaran ongkos dan berbagai variabel yang bersangkutan.

2. Promosi (promotion) adalah suatu unsur yang digunakan untuk memberitahukan dan membujuk pasar tentang produk atau jasa yang baru pada perusahaan, hak dengan iklan, penjualan pribadi, promosi penjualan maupun dengan publisitas.

3. Distribusi (distribution) Memilih dan mengelola saluran perdagangan dimana yang dipakai menyalurkan produk atau jasa dapat mencapai pasar sasaran, mengembangkan sistem distribusi untuk pengiriman dan penanganan produk secara fisik.

4. Orang (people) adalah orang yang melayani ataupun yang merencanakan pelayanan terhadap konsumen.

5. Bukti pisik (physical evidence) yang dimaksud dengan bukti fisik yaitu konsumen akan melihat keadaan nyata dari benda-benda yang dihasilkan jasa tersebut.

6. Proses (proces) penyampingan jasa terjadi di luar pandangan konsumen. Konsumen tidak mengetahui bagaimana proses yang terjadi yang penting jasa yang ia terima harus memuaskan.

7. Produk (product) adalah mengelola unsur produk termasuk perencanaan dan pengembangan produk atau jasa yang tepat untuk dipasarkan dengan mengubah produk atau jasa yang ada dengan menambah dan mengambil tindakan yang lain yang mempengaruhi bermacam-macam produk atau jasa.

Berdasarkan pengertian diatas dapat disimpulkan bahwa bauran pemasaran jasa merupakan unsur-unsur pemasaran yang saling terkait, dibaurkan, diorganisasikan dan digunakan dengan tepat, perusahaan dapat mencapai tujuan pemasaran yang efektif, sekaligus memuaskan kebutuhan dan keinginan konsumen.

\section{Keputusan Konsumen}

Pemasar dalam mencapai keberhasilan harus melewati bermacam-macam pengaruh pembeli dan mengembangkan pemahaman mengenai bagaimana konsumen melakukan keputusan pembelian.

Keputusan konsumen merupakan suatu keputusan sebagai pemilikan suatu tindakan dari dua atau lebih pilihan alternatif (Sumarwan, 2003). Menurut Mowen dan Minor (2002), keputusan konsumen merupakan semua proses yang dilalui konsumen dalam mengenali masalah, mencari solusi, mengevaluasi alternatif, dan memilih di antara pilihan-pilihan pembelian mereka.

Berdasarkan defenisi keputusan konsumen diatas maka dapat dismpulkan bahwa keputusan konsumen adalah semua proses yang dilalui konsumen dalam memilih antara pilihan-pilihan dan niat untuk membeli produk atau jasa yang ditawarkan.

Tahapan keputusan tersebut menurut Kotler (2003), Hawkin (2004), Schiffman \& Kanuk (2004) adalah :

1. Problem Recognition (pengenalan masalah) merupakan tahapan dimana pembeli mengenali masalah atau kebutuhannya. Pembeli merasakan perbedaan antara dengan keadaan aktualnya dengan keadaan yang diinginkan, kebutuhan tersebut dapat dipicu oleh ransangan internal maupun eksternal.

2. Informasi Search (pencarian informasi) merupakan tahapan diamana konsumen berusahan mencari informasi lebih banyak tentang hal-hal yang telah dikenali sebagai kebutuhannya. Konsumen memperoleh informasi dari sumber pribadi, komersial, publik dan sumber pengalaman.

3. Altenatives Evaluation (evaluasi altematif) merupakan tahapan dimana konsumen memperoleh informasi tentang suatu objek dan membuat penilaian akhir. Pada tahap ini konsumen menyempitkan 
pilihan hingga alternatif yang dipilih berdasarkan besamya kesesuaian antara manfaat yang diinginkan dengan yang bisa diberikan oleh plihan produk yang tersedia

4. Purchase Decision (keputusan pembelian) merupakan tahapan dimana konsumen telah memiliki pilihan dan siap melakukan transaksi pembelian atau pertukaran antara uang atau janji untuk membayar dengan hak kepemilikan atau penggunaan suatu barang dan jasa

Post-purchase Behavior (perilaku pasca pembelian) merupakan tahapan dimana konsumen mengalami dua kemungkinan yaitu kepuasan dan ketidak-puasan terhadap pilihan.

\section{Kerangka Analisis}

\section{Bauran Pemasaran Jasa (X)}

1. Physical Evidence (Bukti Fisik)

2. Process (Proses)

3. People (Orang)

\section{Keputusan Wisatawan (Y)}

1. Problem Recognition (Pengenalan Masalah)

2. Informasi Search (Pencarian Informasi)

3. Alternatives Evaluation (Evaluasi Alternaitf)

4. Purchase Decision (Keputusan Pembelian)

5. Post-urchase (Perilaku Pasca Pembelian)

(Kotler,2003), (Hawkin, 2004), (Schiffmn \& Kanuk 2004)

Gambar 1. Kerangka Analisis

\section{METODE PENELITIAN}

Analisis Kuantitatif yaitu metode analisis dengan pengolahan data menggunakan alat-alat statistik program SPSS for windows versi 16 antara lain:

1. Regresi Linier Sederhana

Untuk menghitung besarnya pengaruh bauran pemasaran jasa (X) terhadap keputusan wisatawan (Y) maka digunakan alat analisis regresi linier sederhana dengan rumus sebagai berikut:

$$
\begin{aligned}
& \mathrm{Y}=\mathrm{a}+\mathrm{bX}+\mathrm{e} \text { (Sugiono, 2010:135 ) } \\
& \text { Keterangan : } \\
& \mathrm{Y:} \quad \text { keputusan wisatawan } \\
& \mathrm{X}: \quad \text { bauran pemasaran jasa } \\
& \mathrm{a}: \quad \text { Konstanta } \\
& \text { b: Koefisien regresi } \\
& \text { e: Standar eror }
\end{aligned}
$$

2. Analisis Koefisien Determinasi

Analisis koefisien determinasi digunakan untuk mengetahui seberapa besar pengaruh atau kontribusi variabel tingkat bauran pemasaran jasa dan keputusan wisatawan dengan rumus sebagai berikut:

$R^{2}=\sqrt{\frac{b \sum X Y}{Y^{2}}}$ (Sugiyono, 2010;550)

3. Uji hipotesis

Uji t digunakan untuk mengetahui pengaruh variabel bebas secara parsial terhadap variabel terikat. Uji t yaitu menguji apakah variabel bebas mempunyai pengaruh yang signifikan terhadap nilai variabel terikat dengan rumusan hipotesis sebagai berikut:

$t=\frac{b i}{S b i}$ (Sugiyono, 2010:143)

Dimana:

$\mathrm{t}=$ nilai $\mathrm{t}$ hitung

bi = koefisiensi regresi

Sbi $=$ standar error 
Selanjutnya menjawab rumus adalah dilakukan uji hipotesis dengan uji t yaitu penyajian variabel analisis

$\mathrm{X}$ terhadap variabel $\mathrm{Y}$ secara sendiri-sendiri parsial dengan kriteria sebagai berikut:

1. Jika $t_{\text {sig }}<0,05$ maka Ho ditolak dan Ha diterima, berarti ada pengaruh signifikan antara bauran pemasaran jasa $(\mathrm{X})$ terhadap keputusan wisatawan $(\mathrm{Y})$.

2. Jika $t_{\text {sig }}>0,05$ maka Ho diterima dan Ha ditolak berarti tidak ada pengaruh signifikan antara bauran pemasaran jasa (X) dan terhadap keputusan wisatawan $(\mathrm{Y})$.

\section{HASIL PENELITIAN DAN PEMBAHASAN}

Pantai Panjang Bengkulu terletak sebelah Selatan objek wisata Tapak Paderi dan Benteng Marlborough. Dahulunya objek wisata Pantai Panjang hampir tidak dikenal sebagai objek wisata oleh wisatawan, hal ini karena Pantai Panjang dahulunya merupakan tempat berlabuh kapal-kapal nelayan sekaligus sebagai tempat pendaratan ikan.

Letak Pantai Panjang yang cukup strategis yakni berada di pusat kota yang relatif dekat dengan pusat-pusat keramaian dan dekat dengan objek wisata lainnya menyebabkan objek wisata Pantai Panjang banyak dikunjungi. Tentu saja hal ini merupakan peluang yang cukup menjanjikan untuk dilakukan pengelolaan, agar keberadaan objek wisata Pantai Panjang dapat memberikan masukan bagi pendapatan daerah sektor pariwisata.

\section{Hasil Analisis Data}

\section{Hasil Uji Validitas dan Reliabilitas}

Uji Validitas merupakan tingkat dimana suatu alat pengukur mengukur apa yang seharusnya diukur (Sugiyono, 2008). Sehingga peneliti dapat mengetahui seberapa jauh responden menjawab sesuai yang diinginkan peneliti.

Data penelitian tidak akan berguna apabila instrument yang digunakan untuk mengumpulkan data penelitian itu tidak memiliki validitas yang tinggi. Alat analisis yang digunakan untuk mengukur tingkat validitas data adalah dengan koefisien korelasi menggunakan bantuan software SPSS 17.0.

Tabel 1. Hasil Uji Validitas Instrumen Penelitian

\begin{tabular}{|c|c|c|c|}
\hline No & Aspek, Varibel dan Instrumen & $\begin{array}{l}\text { Nilai } \\
\text { r-hitung }\end{array}$ & Ket \\
\hline \multicolumn{4}{|c|}{ Aspek Bukti Fisik } \\
\hline 1 & Pariwisata yang dikunjungi selalu bersih & $0,470^{*}$ & Valid \\
\hline 2 & Pariwisata berada dilokasi yang mudah untuk dikunjungi & $0,359^{*}$ & Valid \\
\hline 3 & Fasilitas dan jasa yang ada dapat memenuhi kebutuhan dan keinginan & $0,476^{*}$ & Valid \\
\hline \multicolumn{4}{|c|}{ Aspek Proses } \\
\hline 1 & Jalan yang lancar untuk mencapai tempat parawisata & $0,592^{*}$ & Valid \\
\hline 2 & $\begin{array}{l}\text { Untuk mencapai Pantai Panjang sangat mudah karena dekat dengan pusat } \\
\text { kota }\end{array}$ & $0,690^{*}$ & Valid \\
\hline 3 & $\begin{array}{l}\text { Untuk masuk kepariwisata Pantai Panjang Sangat Mudah karena tidak } \\
\text { adanya pemungutan tiket masuk }\end{array}$ & $0,591^{*}$ & Valid \\
\hline \multicolumn{4}{|c|}{ Aspek Orang } \\
\hline 1 & $\begin{array}{l}\text { Para penyedia jasa memberikan pelayanan dengan ramah dan sopan } \\
\text { pada pengunjung }\end{array}$ & $0,538^{*}$ & Valid \\
\hline 2 & Para penyedia jasa memberikan pelayanan yang terbaik pada pengunjung & $0,413^{*}$ & Valid \\
\hline 3 & Para penyedia jasa dapat memenuhi keutuhan wisatawan & $0,478^{*}$ & Valid \\
\hline \multicolumn{4}{|c|}{ Variabel Keputusan Wisatawan } \\
\hline 1 & $\begin{array}{l}\text { Produk dan jasa yang ada dipantai panjang dapat memenuhi kebutuhan } \\
\text { dan keinginan pengunjung }\end{array}$ & $0,538^{*}$ & Valid \\
\hline 2 & Mendapatkan informasi yang baru tentang pantai panjang & $0,413^{*}$ & Valid \\
\hline 3 & $\begin{array}{l}\text { Pariwisata Pantai Panjang adalah pilihan pertama dari pariwisata yang } \\
\text { ada }\end{array}$ & $0,478^{*}$ & Valid \\
\hline 4 & $\begin{array}{l}\text { Memutuskan berkunjung karena Pantai Panjang dapat memenuhi } \\
\text { kebutuhan dan keinginan }\end{array}$ & $0,543^{*}$ & Valid \\
\hline 5 & Merasa puas setelah berkunjung dan menggunakan jasa yang ada & $0,677^{*}$ & Valid \\
\hline
\end{tabular}

Sumber : Hasil Penelitian 2017, diolah 
Korelasi setiap item pertanyaan dengan total nilai setiap variabel dilakukan dengan uji korelasi Pearson. Hasil pengujian validitas instrumen penelitian dapat dilihat pada Tabel 1 . Berdasarkan Tabel 4.16 tersebut, diketahui bahwa seluruh koefisien korelasi item variabel penelitian lebih besar dari nilai r-tabel 0,195. Artinya, seluruh item variabel penelitian valid.

Selanjutnya, uji reliabilitas adalah indeks yang menunjukkan sejauh mana suatu relative konsisten apabila pengukuran diulangi dua kali atau lebih (Sugiyono, 2008). Dalam setiap penelitian, sering terjadi adanya kesalahan pengukuran yang cukup besar. Suatu penelitian dapat dipercaya apabila dalam beberapa kali pengukuran terhadap suatu kelompok dengan subyek yang sama akan menghasil kan hasil yang sama. Pengujian reliabilitas setiap variabel dilakukan dengan Cronbach Alpha Coeficient menggunakan bantuan software SPSS 17.0. Data yang diperoleh akan dapat dikatakan reliable apabila nilai Cronbach's Alpha lebih besar atau sama dengan 0,6 (Sekaran, 2001). Hasil pengujian reliabilitas variabel penelitian dapat dilihat pada Tabel 2. berikut ini.

Tabel 2. Hasil Uji Reliabilitas Instrumen Penelitian

\begin{tabular}{|l|l|c|c|c|}
\hline No & Aspek dan Variabel & $\begin{array}{l}\text { Jumlah } \\
\text { Instrumen }\end{array}$ & $\begin{array}{l}\text { Nilai Alpha } \\
\text { Cronbach }\end{array}$ & Keterangan \\
\hline 1 & Aspek Bukti Fisik & 3 & 0,672 & Reliabel \\
\hline 2 & Aspek Proses & 3 & 0,790 & Reliabel \\
\hline 3 & Aspek Orang & 3 & 0,612 & Reliabel \\
\hline 4 & Keputusan Wisatawan & 5 & 0,767 & Reliabel \\
\hline
\end{tabular}

Sumber : Hasil Penelitian 2017, diolah

Berdasarkan hasil analisis data sebagaimana ditunjukkan pada Tabel 2. diketahui bahwa seluruh koefisien Alpha Cronbach variabel penelitian lebih besar dari nilai 0,6; yang berarti bahwa seluruh instrumen penelitian adalah reliabel (handal).

\section{Hasil Analisis Regresi}

Analisis regresi linier sederhana digunakan untuk mengetahui pengaruh bauran pemasaran jasa terhadap keputusan wisatawan berkunjung ke Pantai Panjang Bengkulu. Hasil analisis regresi secara lengkap ditampilkan pada tabel 3. berikut.

Tabel 3. Hasil Analisis Pengaruh Implementasi Bauran Pemasaran Jasa terhadap Keputusan Wisatawan

\begin{tabular}{clcccc}
\hline No & \multicolumn{1}{c}{ Variabel Bebas } & $\begin{array}{c}\text { Koefisien } \\
\text { Regresi }\end{array}$ & $\begin{array}{c}\text { Nilai } \\
\text { t-hitung }\end{array}$ & $\begin{array}{c}\text { Probabilitas } \\
\text { (Sig.) }\end{array}$ & Keterangan \\
\hline 1 & Bauran Pemasaran & 0,227 & 2,757 & 0,007 & Signifikan \\
2 & Konstanta & 11,012 & & & \\
3 & $\mathrm{R}$ & 0,770 & & & \\
4 & $\mathrm{R}^{2}$ & 0,593 & & & \\
5 & Adjusted R ${ }^{2}$ & 0,561 & & & \\
6 & F-hitung & 7,602 & & \\
7 & F-tabel & 2,300 & & \\
8 & t-tabel & 2,045 & & & \\
\hline
\end{tabular}

Sumber : Hasil Penelitian, 2017

Berdasarkan Tabel 3. di atas, persamaan regresi yang diperoleh dalam penelitian ini adalah sebagai berikut:

\section{$\mathrm{Y}=\mathbf{1 1}, \mathbf{0 1 2}+\mathbf{0 , 2 2 7 \mathrm { X }}$}

Dengan penjelasan sebagai berikut:

1. Nilai konstanta sebesar 11,012 berarti bahwa jika variable bauran pemasaran jasa sama dengan nol, maka keputusan wisatawan berkunjung ke Pantai Panjang Bengkulu konstan (tetap) sebesar 11,012 .

2. Nilai koefisien regresi variabel bauran pemasaran jasa sebesar 0,227 yang berarti bahwa jika bauran pemasaran jasa semakin baik, maka keputusan wisatawan berkunjung ke Pantai Panjang Bengkulu akan meningkat sebesar 0,227.

Dari hasil analisis regresi juga diperoleh nilai koefisien korelasi berganda (R) sebesar 0,770; kondisi ini berarti bahwa hubungan antara bauran pemasaran jasa (bukti fisik, proses, dan orang) dengan 
keputusan konsumen adalah cukup kuat. Koefisien determinasi berganda $\left(\mathrm{R}^{2}\right)$ sebesar 0,593; bermakna bahwa kenaikan dan penurunan keputusan konsumen sebesar 59,3 persen dapat dijelaskan oleh bauran pemasaran jasa (bukti fisik, proses, dan orang), sedangkan sisanya 40,7 persen dipengaruhi oleh faktor lain yang tidak diteliti.

\section{Hasil Pengujian Hipotesis}

Untuk membuktikan pengaruh bauran pemasaran jasa yang terdiri dari people, physical evidence, dan process terhadap keputusan wisatawan berkunjung ke Pantai Panjang Bengkulu maka dilakukan pengujian hipotesis. Pengujian hipotesis dilakukan dengan uji t. Kriteria pengujiannya adalah sebagai berikut:

- Jika probabilitas (sig.) < alpha 0,05; maka secara parsial variabel implementasi bauran pemasaran jasa (bukti fisik, proses, dan orang) berpengaruh signifikan terhadap keputusan wisatawan berkunjung ke Pantai Panjang Bengkulu (Ho ditolak dan Ha diterima).

- Jika probabilitas (sig.) > alpha 0,05; maka secara parsial variabel implementasi bauran pemasaran jasa (bukti fisik, proses, dan orang) tidak berpengaruh signifikan terhadap keputusan wisatawan berkunjung ke Pantai Panjang Bengkulu (Ho diterima dan Ha ditolak).

Berdasarkan hasil analisis data sebagaimana terangkum pada Tabel 3. diketahui bahwa nilai thitung variabel bauran pemasaran jasa sebesar 2,757 dengan signifikansi 0,007 < alpha 0,05; yang berarti bahwa variabel implementasi bauran pemasaran jasa (bukti fisik, proses, dan orang) berpengaruh secara signifikan terhadap keputusan wisatawan berkunjung ke Pantai Panjang Bengkulu.

\section{Pembahasan}

Hasil penelitian menunjukkan bahwa bauran pemasaran jasa yang dilakukan oleh Pemerintah Bengkulu berpengaruh signifikan terhadap keputusan wisatawan berkunjung ke Pantai Panjang Bengkulu. Kondisi ini berarti bahwa program pemasaran merupakan komponen yang sangat penting dalam memberikan rasa puas kepada konsumen. Menciptakan rasa puas pada konsumen merupakan suatu tindakan paling strategis dibandingkan dengan usaha perusahaan mencari pelanggan baru. Konsumen yang merasa puas, tentu saja akan berdampak pada penyedia jasa itu sendiri. Konsumen selain sebagai tujuan akhir pemasaran, juga sebagai media promosi hidup yang sangat efisien. Sekali konsumen merasa puas, maka konsumen tersebut akan memberikan informasi positif kepada orang lain mengenai pelayanan penyedia jasa. Sebaliknya, jika konsumen tidak puas, maka informasi yang akan disampaikan kepada orang lain akan bersifat negatif dan dapat mempengaruhi hubungan antara konsumen dengan penyedia jasa.

\section{KESIMPULAN}

1. Persamaan regresi yang diperoleh dari hasil analisis data adalah : $\mathbf{Y}=\mathbf{1 1 , 0 1 2}+\mathbf{0 , 2 2 7 X}$, yang bermakna jika bauran pemasaran jasa semakin baik, maka keputusan wisatawan berkunjung ke Pantai Panjang Bengkulu akan meningkat sebesar 0,227.

2. Variabel bauran pemasaran jasa (bukti fisik, proses, dan orang) berpengaruh secara signifikan terhadap keputusan wisatawan berkunjung ke Pantai Panjang Bengkulu yang dibuktikan dengan nilai t-hitung 2,757 dengan signifikansi 0,007 < alpha 0,05.

3. Besar kecilnya keputusan wisatawan berkunjung ke Pantai Panjang Bengkulu sebesar 59,3 persen dapat dipengaruhi oleh bauran pemasaran jasa (bukti fisik, proses, dan orang), sedangkan sisanya 40,7 persen dipengaruhi oleh faktor lain di luar penelitian.

\section{DAFTAR PUSTAKA}

Boyd, Walker dan Larreche (2000; 123) .Manajemen Pemasaran, Edisi Kedua, Jilid 1,Penerbit Erlangga, Jakarta.

Kotler, Philip dan Gary Armstrong, 2001, Prinsip-prinsip Pemasaran, Jilid 1, Edisi Kedelapan, Jakarta, Erlangga

Kotler, Philip, 2000, Manajemen Pemasaran, Edisi Milenium, Jakarta, Prehallindo.

Kotler, Philip. 2001. Manajemen Pemasaran: Analisis, Perencanaan, Implementasi dan Kontrol. Jakarta: PT. PrehallindoBuchari Alma, 2004, Manajemen Pemasaran dan Pemasaran Jasa, Edisi Revisi, Bandung, Alfabeta. 
Kotler, Philip.2003. Manajemen Pemasaran. Edisi kesebelas, Jakarta: Indeks kelompok Gramedia Hawkin (2004) Hawkins et al.(2004). Consumer Behavior. New York: Mc Graw Hill,

Mowen, JC dn Minor, M. (2002). Consumer Behavior Fifth Edition. New Jersey: Prentice-Hall

Schiffman, Leon G. Kanuk, Leslie Lazar. (2004).Consumer Behavior . 9 th ed. PrenticeHall. New Jersey: Upper Saddle River.

Sumarwan, Ujang. 2003. Perilaku Konsumen : Teori dan Penerapannya Dalam Pemasaran. PT. Ghalia Indonesia. Bogor

Swastha, Basu, T. Hani Handoko, 2001. Manajemen Pemasaran Analisis Perilaku Konsumen , Edisi2, Liberty. Yogyakarta. 